\title{
Frivillige vågeres ulønnede arbejde hos døende \\ - stedfortrædende omsorgsarbejde på nærværets betingelser
}

\author{
Karen Sangild Stølen, Michael Hviid Jacobsen \& Mette Raunkiaer
}

Omsorg for døende borgere i palliative plejeforløb i eget hjem og på plejehjem er en kommunal opgave. Frivillige tilbyder at være med til at løfte denne velfærdsopgave. Dette kvalitative studie undersøger to forskningsspørgsmål: (1) Hvad kendetegner frivillige vågeres arbejde, når de sidder hos døende? (2) Hvilke udfordringer og/eller muligheder er knyttet til grænser mellem frivilligt og professionelt arbejde hos døende i palliative plejeforløb? Deltagerobservation og interviews udgør studiets metoder. Fire plejehjem i to kommuner og to vågegrupper gav adgang til observationer. 65 timers deltagerobservation af vågernes arbejde i palliative plejeforløb og fællesmøder samt 16 interviews med vågere, pårørende og professionelle udgør studiets empiriske materiale. Fænomenologisk omsorgsfilosofi og et symbolsk interaktionistisk 'boundary-work'-perspektiv udgør den teoretiske ramme. Det konkluderes, at vågernes frivillige arbejde er kendetegnet ved sansende og stedfortrædende omsorg, hvor tid hos den døende giver erfaringer af særlig betydning. Grænser mellem det frivillige og det professionelle arbejde markeres og opretholdes af både vågere og professionelle. Vågerne overskrider og udvider grænser på nærværets betingelser i situationsspecifik omsorg for døende og deres pårørende.

Nøgleord: Frivillig, våger, døende, palliativ omsorg, eget hjem, plejehjem

\section{Introduktion}

Døden i det senmoderne samfund og det, der har med døden at gøre er blevet noget, vi forventer, at institutioner og professionelle tager sig af (Jacobsen 2011). Af de ca. 53.000 personer, der årligt dør i Danmark, dør cirka halvdelen på hospitaler, halvdelen på et plejecenter eller i eget hjem og ca. 5\% dør på hospice eller andre steder (Jarlbæk, 2017). Den gennemsnitlige levetid for en borger på landets plejecentre er ca. 30 mdr.
(Schwartz-Nielsen \& Raunkiær, 2015), og knapt en tredjedel af borgerne bor der mindre end et år (Sundheds- og Ældreministeriet, 2016). Professionel pleje, omsorg og behandling til døende omfattes af det, der i en sundhedsfaglig sammenhæng defineres som palliation (Timm, 2014; Sundhedsstyrelsen, 2017). I disse år tilbyder frivillige vågere i stigende grad deres støtte i disse palliative plejeforløb både på hospitaler, hospice og på plejecentrene. Vågerne, som denne artikel har 
fokus på, inviteres helt tæt på den døende for at sidde og våge der, hvor ingen andre er til stede. Deres frivillige arbejde ses som en reaktion på, at et stigende antal danskere årligt dør alene uden hverken en professionel eller pårørende ved deres side (Ældre Sagen, 2019a, Riisgaard, 2015). Såfremt vågere i palliative plejeforløb skal opfattes som en del af velfærdsstatslige tilbud til døende og deres pårørende, bliver det væsentligt at forstå, hvad det er, vågerne gør hos døende, når de professionelle ikke er til stede. Samtidig bliver det væsentligt at forstå, hvor grænserne går mellem det, vågerne gør for og hos den døende i forhold til de professionelles arbejde der.

De sundhedsprofessionelles faglige organisationer anerkender det frivillige arbejde som en ekstra ressource i omsorgsarbejde, men har også opmærksomhed på dilemmaer knyttet til de flydende grænser mellem hvilke opgaver, der kan/skal løses af frivillige og hvilke opgaver, der skal varetages af de sundhedsprofessionelle (FOA, 2017; DSR, 2011). Et væsentligt emne i den offentlige debat er, om frivilliges arbejde udelukkende supplerer den offentlige velfærd, eller mere strategisk indgår som en del af de ressourcer, kommuner og regioner medregner, når der skal planlægges velfærd (Bertelsen, 2015). Når frivillige engageres hos døende i palliative plejeforløb, er dette dermed også et udtryk for en type frivillighed, der bidrager med noget, men det er langt mere uklart, hvad det er, vågerne bidrager med, og hvordan deres arbejde kan forstås i relation til de professionelles omsorgsarbejde for den døende. Formålet med denne artikel er at undersøge frivillige vågeres arbejde i palliative plejeforløb i eget hjem, hvor eget hjem også omfatter plejeboliger. Afsættet for artiklen er følgende to forskningsspørgsmål: (1) Hvad kendetegner de frivillige vågeres arbejde, når de sidder hos døende? (2) Hvilke udfordringer og/eller muligheder er knyttet til grænser mellem det frivillige og det professionelle arbejde hos døende i disse palliative plejeforløb? Det palliative plejeforløb, som denne artikel sætter fokus på, er den afsluttende del, hvor borgerens sygdom og tilstand indebærer, at døden er nært forestående, og betegnes som den terminale palliative del af et plejeforløb (Spile, 2018).

\section{Forskning om frivillighed i palliative forløb}

International forskning argumenterer bredt for at involvere frivillige i palliative forløb og der argumenteres for, at frivillige kan bidrage med støtte relateret til emotionelle og praktiske områder hos både den syge og den syges pårørende (Candy, France, Low \& Sampson, 2015; Howlett \& Scott, 2018; Walshe et al. 2016). De fleste studier har forsket i frivillighed knyttet til hospice (Claxton-Oldfield, 2007; Morris, Wilmot, Hill, Ockenden \& Payne , 2013; Wilson, Justice, Roger \& Sheps , 2005), og kun få studier undersøger frivilliges arbejde hos døende i eget hjem, som dette studie adresserer. En del studier i dansk og nordisk sammenhæng har forsket i frivilliges rolle set i relation til den offentlige velfærd (Henriksen, 2019, Strømsnes \& Svedberg; Boye, 2017; La Cour, 2014), mens forskning på det sundhedsmæssige område relateret til en borgers sidste levetid, er meget begrænset. Norske studier har undersøgt frivilliges betydning for en værdig ældreomsorg (Abrahamsen, 2010; Hillestad \& Tessem, 2015). I dansk sammenhæng har Poort (2010) undersøgt frivillighed relateret til uhelbredeligt kræftsyge i hospitalsregi. Hun konkluderer, at kræftpatienter oplever den frivillige som en fremmed, men som et medmenneske med tid og lyst til at være til stede og understøtte den syges oplevelse af normalitet. Overgaard (2014a) har haft fokus på frivilliges omsorgsarbejde på hospice og sammenligner frivillighed på et dansk hospice med frivillighed på et australsk hospice. Hun konkluderer, at 
danske hospicefrivillige i højere grad end de australske frivillige udelukkes fra pleje- og omsorgsarbejde. Overgaard (2014b) opfordrer danske sundhedsprofessionelle til at tænke nyt om frivilliges potentiale i den palliative omsorg og pleje med afsæt i, hvad der gavner borgeren mere end, hvordan man traditionelt tænker arbejdsopgaverne fordelt. Fristrup og Holm Laursens (2017) mindre etnografiske og selvbiografiske studie om det at våge hos en døende borger i et privat hjem viste, at vågerens sanselige orientering er det, der guider vågeren i kontakten til den døende i det ordløse rum. Denne artikel supplerer dansk forskning om frivilliges omsorgsarbejde i palliative forløb ved at inddrage en ny kontekst, nemlig eget hjem (her forstået som både privat bolig og plejehjem).

\section{Teoretisk ramme}

I det følgende præsenteres artiklens teoretiske ramme, hvor to teoretiske tilgange med ophav i forskellige teoretiske traditioner kombineres og samlet bidrager til at udfolde datamaterialet og besvare forskningsspørgsmålene. Fænomenologisk omsorgsfilosofi belyser særligt forskningsspørgsmål 1 og temaer relateret hertil - dvs. de særlige kendetegn ved vågernes omsorgsarbejde. Derudover inddrages et symbolsk interaktionistisk perspektiv, der belyser og udfolder datamaterialet i forhold til forskningsspørgsmål 2, herunder hvad der kan være på spil i samhandlinger de involverede parter imellem i den pågældende kontekst, når de frivillige vågere inviteres ind i omsorgsarbejdet hos døende i palliative plejeforløb i eget hjem. Disse to teoretiske tilgange supplerer således gensidigt hinanden og kaster hver især lys over forskellige dele af datamaterialet.

\section{Foenomenologisk omsorgsfilosofi}

Martinsens teori om omsorg, ikke bare som sygeplejens værdigrundlag, men som noget universelt og eksistentielt i al menneskelig sameksistens, gør den anvendelig til at indfange væsentlige fænomener ved frivilliges omsorgshandlinger. I denne artikel bruges særligt begreber hos Martinsen inspireret af Løgstrup, for hvem "omsorg for den anden viser sig i de menneskelige relationer, i tilliden, den åbne tale, håbet og barmhjertigheden" (Alvsvåg, 2015, s. 189). Disse fænomener kalder Løgstrup for de spontane livsytringer, der er førkulturelle kendetegn ved al menneskelig eksistens (ibid.). Hos Martinsen er sansning primær i omsorgen. Igennem sansning kan de spontane livsytringer få plads. Sansning går hos Martinsen forud for ord mellem mennesker (Martinsen 2000). Med henvisning til Løgstrup beskrives begrebet sansningens stemthed som: "den modtagelighed der skal til, for at noget overhovedet kan gøre indtryk på os" (Martinsen, 2018, s. 33). At kunne lade sig bevæge er i denne forståelse dermed centralt i omsorgen for den anden. Brugen af sanserne er en forudsætning for at kunne tolke og tyde den anden men også nært knyttet til en moralsk dimension, der indebærer bevidsthed om, at alle forhold mellem mennesker indebærer magt og afhængighed, og det kræver moralsk ansvarlighed ikke at misbruge denne magt (Alvsvåg, 2015; Martinsen, 2000). Særligt centralt bliver dette, når den anden er $\mathrm{i}$ en sårbar livssituation og afhængig af hjælp, som det f.eks. gør sig gældende i relationen mellem den frivillige våger og den døende og de pårørende. Martinsens forståelse af begrebet 'sansning' bruges i denne artikel til at belyse de frivillige vågeres ordløse omsorgshandlinger hos den døende borger, der ofte ikke har kræfterne til at føre en samtale, og hvor vågeren på andre måder end med brug af ord og almindelig samtale må forsøge at vise tilstedeværelse og forstå den, de sidder hos. 
Martinsen (2018) argumenterer for, at mennesker kan anvende sanserne i en genopdagelse af særlige øjeblikkes betydning. Hun bruger begrebet 'hellig' om dét, vi som mennesker knytter til særlige tider og øjeblikke i vores liv. Dette 'hellige' er imidlertid ikke noget, vi har magt over, men noget vi sansemæssigt gribes af. Det kan være forbundet med det, vi erfarer sammen med et andet menneske, f.eks. fænomenet tillid eller følelsen af noget særligt, når vi er i kontakt med det skabte og naturen. Denne type følelser er tilgængelige for alle uanset livsholdninger eller tro (ibid.). Disse værdifulde øjeblikke i menneskers liv er ofte skjult for andre, men sanses, mærkes og gør indtryk. Erfaringer med det hellige sætter sig som spor i kroppen, og disse erfaringer trækker vi mennesker på i forskellige livssituationer (ibid.). Mulighed for denne type erfaring er i Martinsens forståelse knyttet til tid. Med henvisning til Rosa (2014) beskriver hun, hvordan tidsrelaterede krav og normer har karakter af noget totalitært, der kan fortrænge den tidsopfattelse, som kroppen er indfældet i fra naturens hånd (ibid.). Martinsen problematiserer, hvordan dét, at samfund lader sig styre af klokketid, løsriver menneskets tidsopfattelse fra naturens tid, hvilket har betydning for menneskers evne til at være til stede hos den anden i tid. Også selvom denne måde at bruge tid på ikke altid er synlig for andre eller ser ud til at bidrage med noget målbart eller produktivt (ibid.). Martinsens tanker om vore sansers betydning for at kunne indfange og bevæges af de særlige øjeblikke, og dermed få erfaringer med berøring af noget, der opleves helligt, bruges i denne artikel til at belyse de frivillige vågeres erfaringer og oplevelser omkring selve dødens øjeblik hos den døende.

Med henvisning til Løgstrup og Bjerg udfolder Martinsen (2000) begrebet "stedfortrædelse" som et universelt anliggende i mellemmenneskelige relationer og derfor også som en central del af omsorgen. Sted- fortrædelse betyder 'i stedet for' eller 'i den andens sted', og er i denne forståelse aldrig en erstatning, der fortrænger eller sætter den aflastede udenfor, men en midlertidig stedfortrædelse indtil den anden igen kan vende tilbage til sit sted (Martinsen, 2000). Ifølge Martinsen kan ikke hvem som helst være en andens stedfortræder. Det kræver kendskab til situationen på en vedkommende måde og evne til at kunne tyde den anden. Stedfortræderen må endvidere have respekt for den anden, således at den magt, der er knyttet til den tillid, der vises stedfortræderen, ikke misbruges (ibid.). I denne artikel anvendes begrebet 'stedfortrædelse' til at udfolde et centralt kendetegn ved de frivillige vågeres omsorgshandlinger, når de som fremmede sidder hos den døende, fordi ingen andre sidder der.

\section{'Boundary-work'}

Som afsæt til at forstå udfordringer og/eller muligheder knyttet til grænserne mellem de frivilliges ulønnede omsorgsarbejde og de professionelles arbejde anvendes her et 'boundary-work'-perspektiv. Begrebet er oprindeligt introduceret af Gieryn (1983), der beskrev, hvordan forskere markerede grænser mellem forskere og ikke-forskere. Selvom 'boundary-work' således er udviklet inden for en videnskabsfilosofisk kontekst, og selvom det er udfoldet og udviklet inden for mange forskellige forskningsmæssige kontekster (Lamont \& Molnár, 2002), så er begrebets sammenkobling med 'work' teoretisk inspireret af symbolsk interaktionisme (Fournier, 2000; van Bochove, Tonkens, Verplanke \& Roggeveen, 2018).

Van Bochove et al. (2018) beskriver, hvordan både frivillige og professionelle har måder, hvorpå de konstruerer og rekonstruerer grænser for at beskytte egen position og rolle i arbejdet. Om dette anvender de begrebet 'demarcation-work'. Begrebet betegner de 
grænsedragninger, som parterne markerer i forhold til forskelle i viden og færdigheder, status og autoritet samt forhold vedrørende forskelle i dét, man gensidigt kan forvente af hinandens arbejde. Dette er alt sammen forhold, der i større eller mindre grad er forventelige og legitimerer opretholdelse af de konstruerede grænser mellem parterne (ibid.). I tillæg til 'demarcation-work' argumenterer forskerne for en yderligere dimension af 'boundary-work' (ibid.). Denne dimension omhandler situationer, hvor de frivillige inviteres ind i det, der traditionelt er de professionelles faglige domæne. Et eksempel med relevans for denne artikel er, når frivillige vågere inviteres ind i plejeforløb for døende, samtidigt med at professionelle har hovedansvaret for plejeforløbet. Denne type 'boundary-work' beskrives af de hollandske forskere som 'welcoming-work' og adskiller sig fra 'demarcation-work', da en sådan invitation indebærer, at tidligere konstruerede grænser rekonstrueres og forhandles på ny og dermed snarere omdannes end overskrides (ibid.). Hos van Bochove et al. er 'welcoming-work' betinget af strukturelle og samfundsmæssige forhold, herunder ikke mindst udtryk for stigende arbejdspres og nedskæringer i offentlig velfærd men også for den status, det professionelle omsorgsarbejde, særligt på plejehjem, traditionelt har været tilregnet (ibid.).

Således bidrager artiklens to teoretiske perspektiver på hver deres måde til både at udfolde vågernes omsorgshandlingers fænomenologiske kendetegn og betydning set i relation til de involverede parter i plejeforløbet, men også til at forstå disse i lyset af de bredere samfundsmæssige tendenser, som disse omsorgshandlinger er en reaktion på. I det følgende præsenteres studiets kontekst, design og metode samt etiske overvejelser.

\section{Kontekst, design og metode}

Da studiet søger viden om vågeres handlinger, blev der etableret kontakt til to organiserede frivillige vågetjenester i Dansk Røde Kors og Ældre Sagen. Disse velfærdsorganisationer har gennem de sidste mange år tilbudt frivillig vågning hos døende borgere i eget hjem og på plejehjem og i de senere år oplevet en stigende efterspørgsel på dette (Dansk Røde Kors, 2018, 2019; Ældre Sagen, 2019b). Studiets metode var en kombination af deltagerobservationer og interviews. Deltagerobservationer foregik til vågernes fællesmøder, og når de vågede hos en døende borger i et palliativt plejeforløb. De opfølgende interview var med vågerne, pårørende til døende borgere, der var våget hos og professionelle involverede i disse plejeforløb. Interview med den døende borger var ikke muligt i studiets inkluderede plejeforløb. Fire plejehjem i to forskellige kommuner gav adgang til observationer, når de havde plejeforløb, hvor vågere var involveret. Disse plejehjem havde et etableret samarbejde med en vågetjeneste. Involvering af flere plejehjem gav en variation af muligheder for observationer i den planlagte periode. To af de fire plejehjem havde vågere involveret i plejeforløb hos døende i den planlagte observationsperiode. Tre vågeforløb foregik i tilknytning til plejeboliger, og ét vågeforløb foregik i en borgers private hjem, hvor hjemmeplejen fra kommunen var tilknyttet plejeforløbet. Vågningerne i plejebolig foregik typisk fra kl. 22.00-06.00 og lå på alle ugens dage. Vågeforløbet i eget hjem foregik i en periode over to måneder. Deltagerobservation som undersøgelsesmetode er ifølge Kristiansen \& Krogstrup (2015) velegnet til at få viden om mennesker i deres egne omgivelser eller en bestemt social praksis, som i dette tilfælde vågernes praksis. Der blev udarbejdet en åben observationsguide med spørgsmål som: Hvad sker der i rummet? Hvem gør hvad? Hvad gøres ikke? Hvad siges der? Hvad siges 
der ikke? Vågernes fællesmøder gav indsigt i, hvad der optog vågerne. F.eks. fyldte dilemmaer om støtte til pårørende meget tid i vågernes fælles drøftelser på møderne. En væsentlig indsigt, der ikke kunne indfanges under observation af vågerne hos den døende i et rum med få ord, hvor vågeren mest var alene med observatøren og den døende. Feltnoter blev nedskrevet inden for 24 timer for at fastholde detaljer og inspirere de opfølgende interview. Både feltnoter og transskriberede interview indgik som analysemateriale. Det kvalitative interview gav adgang til informanternes egne oplevelser og erfaringer om det eller de fænomener, der skulle undersøges (Tanggaard \& Brinkmann, 2015). At supplere interview af vågerne med interviews med de involverede parter i disse vågeforløb (pårørende og professionelle) gav anledning til flere nuancer og perspektiver på fænomenet. F.eks. blev fund relateret til vågernes 'stedfortrædelse' set i observatio- ner, men først tydelige og endelig valideret som et fund gennem interview med både de pårørende og de professionelle. Semi-strukturerede interviewguides dannede afsæt og retning for interviews med de involverede parter. Spørgsmålene var organiseret inden for overordnede temaer som f.eks., hvad gør og gør vågeren ikke under en vågning, hvordan vurderes hvad den døende har brug for, hvornår var noget vanskeligt osv. De frivillige fik også spørgsmål relateret til emner taget op ved fællesmøder. Interviewene blev foretaget enten som individuelle eller gruppeinterviews og havde en varighed fra 45-90 minutter. I alt deltog 25 informanter i enten et individuelt eller et gruppeinterview. Syv vågere stillede sig til rådighed for observation i forbindelse med fire vågeforløb. De interviewede vågere var i alderen 45-78 år. To af de i alt 32 deltagende vågere var mænd. Interviewene blev transskriberet ordret med softwareprogrammet Express Scribe.

\section{Oversigt over deltagerobservationer og interview}

\begin{tabular}{|c|c|c|c|}
\hline $\begin{array}{l}\text { Deltagerobservation } \\
65 \text { timer }\end{array}$ & $\begin{array}{l}\text { Frivillige vågere } \\
13 \text { informanter }\end{array}$ & $\begin{array}{l}\text { Professionelle } \\
9 \text { informanter }\end{array}$ & $\begin{array}{l}\text { Pårørende } \\
3 \text { informanter }\end{array}$ \\
\hline $\begin{array}{l}4 \text { vågeforløb i eget } \\
\text { hjem (Et forløb i } \\
\text { privat bolig og tre } \\
\text { forløb på plejehjem) } \\
\text { (7 vågere involveret) } \\
\text { Vågernes fællesmøder } \\
\text { og arrangementer }\end{array}$ & $\begin{array}{l}5 \text { individuelle } \\
\text { interview (heraf } \\
3 \text { vågeledere) } \\
3 \text { gruppeinterview } \\
\text { med i alt } 8 \text { deltagere }\end{array}$ & $\begin{array}{l}2 \text { individuelle } \\
\text { interview ( } 2 \text { syge- } \\
\text { plejersker med ansvar } \\
\text { for palliative forløb) } \\
3 \text { gruppeinterview } \\
\text { med i alt } 7 \text { deltagere } \\
\text { (ansatte i hjemme- } \\
\text { pleje og på plejehjem) }\end{array}$ & $\begin{array}{l}3 \text { individuelle in- } \\
\text { terview ( } 2 \text { voksne } \\
\text { efterlevende døtre og } \\
1 \text { efterlevende ægte- } \\
\text { fælle) }\end{array}$ \\
\hline
\end{tabular}

Deltagerobservationer og interviews foregik i perioden fra 15.08.2018-01.04.2019.

\section{Etiske overvejelser}

De to vågegrupper gav mundtligt samtykke til at forskere kunne observere ved fællesmøder og i vågeforløb, hvor de samarbejdende institutioner og den døende borger og/eller pårørende havde givet samtykke til dette. Vågerne i de observerede vågeforløb gav individuelt skriftligt informeret samtykke forud for observationen. Der blev etableret møde med ledere på de plejehjem, som vågerne 
samarbejdede med og indhentet skriftligt informeret samtykke om institutionens deltagelse. Plejehjemslederne havde ansvaret for at informere personale, beboere og pårørende om projektdeltagelsen gennem personalemøder, stedets fælles mails og/eller elektroniske info-skærme. Alle involverede institutioner modtog skriftligt materiale om projektets formål. Ledere knyttet til plejeområdet i den kommunale administration blev orienteret om projektet gennem et møde forud for projektets opstart. I to ud af de fire observerede vågeforløb var den døende borger ikke kontaktbar. Her gav nærmeste pårørende mundtligt samtykke. I de øvrige vågeforløb gav både borgeren og nærmeste pårørende mundtligt samtykke forud for observationen. Alle institutioner, vågere, professionelle og pårørende var således vidende om og havde givet tilladelse til studiets observationsdel. Herudover gav informanter, der deltog $\mathrm{i}$ interviews, skriftligt informeret samtykke til deltagelse. Ifølge Brinkmann (2015) involveres vore værdier og etiske overvejelser særligt, når menneskers personlige liv og erfaringer gøres til genstand for analyse og offentlighed, f.eks. i et forskningsprojekt. Dette har gennem hele forskningsprocessen betydet en særlig opmærksomhed i form af at lade hensynet til de enkelte informanter gå forud for hensynet til projektets forskningsinteresse. F.eks. blev observation af et vågeforløb afbrudt og er ikke medtaget $\mathrm{i}$ datamaterialet, fordi den døende borger, på trods af samtykke fra nærmeste pårørende, viste tegn på mere uro ved flere personer $\mathrm{i}$ rummet. Principperne for 'The Danish Code of Conduct for Research Integrity' er således overholdt gennem hele forskningsprocessen (Uddannelses- og Forskningsministeret, 2014), og alle data er behandlet i henhold til Persondataloven (GDPR, 2018).

\section{Analysestrategi}

Analysen er foregået tematisk med afsæt i Braun \& Clarkes (2006) 'step by step guide' for tematiske analyser: (1) Alle interview blev gennemlyttet, transskriberet og læst sammen med feltnoter for at få fortrolighed med materialet. (2) Alle datasæt blev systematisk kodet og gentagne temaer identificeret og knyttet til tekstuddrag. (3) Sortering af koder til potentielle overordnede og underordnede temaer på tværs af materialet. (4) Potentielle temaer med tekstuddrag blev genbesøgt og førte til endnu en sortering. (5) De endelige temaer blev forfinet gentagne gange frem til endelig beslutning om overordnede og underordnede temaer. Løbende gennem denne proces blev flere teoretiske perspektiver afprøvet og med afsæt i, hvad der bedst kunne udfolde de fremkomne fænomener i empirien og give svar på artiklens undersøgelsesspørgsmål, blev to teoretiske perspektiver valgt ud (se afsnittet 'Teoretisk ramme'). Selve analysestrategien har således været en systematisk fremadskridende, men samtidig fleksibel vekslen mellem en fænomenologisk inspireret induktiv proces og en mere teoretisk- og begrebsinspireret deduktiv proces frem mod følgende endelige fremanalyserede temaer og undertemaer:

Tema 1: Det frivillige omsorgsarbejde

- Det sansende nærvær

- Tid til særlige øjeblikke

- Stedfortræder

Tema 2: Grænser i omsorgsarbejdet

- Ingen grænser uden undtagelser

- De uundgåelige dilemmaer

- Grænser der udvides

I det følgende præsenteres studiets fund. Første hovedtema knytter an til svar på artiklens første forskningsspørgsmål, mens andet hovedtema knytter an til artiklens andet forskningsspørgsmål. 


\section{Fund}

\section{Det frivillige omsorgsarbejde}

Studiets observationer viste, at vågerne brugte deres egne fornemmelser for at kunne tyde det menneske, de sad hos og tolke, hvilke behov vedkommende så ud til at have. Deres omsorgshandlinger var kendetegnet ved, at de kreativt benyttede sig af forskellige måder til at opnå fornemmelse for, hvad den døende havde brug for. Det at have tid og give sig tid til at være hos den døende var centralt for vågerne, og gav dem særlige muligheder i mødet med den døende.

\section{Det sansende noervor}

Når vågerne sad hos den døende, brugte de deres sanser i forsøget på at tyde og forstå det menneske, de sad hos. Det fysiske rum blev undersøgt grundigt. Det fortalte vågeren noget om, hvem den, de sad hos, var, og hvilket liv vedkommende havde levet. Stole blev flyttet stille rundt i rummet i takt med den døendes ændrede lejringer for at sidde vendt mod den døende borger og opfange de mindste tegn eller lyde fra vedkommende. I det ordløse rum blev der lyttet opmærksomt til den døendes lyde, og vågerne brugte deres hænder til at give den døende et tegn på, at de var til stede. De rørte f.eks. vedkommende let på armene og måske forsigtigt i ansigtet eller på panden. Den fysiske berøring brugte vågerne også til at mærke, hvorvidt den døende borger var varm eller mere kølig på huden for at få en fornemmelse af dødens proces. De fornemmede lugtene i rummet og fra den døende, som også kunne være vigtige tegn relateret til dødens naturlige proces. I den følgende feltnote blev der våget hos en kvinde, der hele sit liv havde været døv. Nu var den ældre kvinde døende og sov dybt. Vågeren sad hos kvinden og holdt hende skiftevis let i hånden og forsigtigt på armen, mens hun stille hviskede henvendt til observatøren:

"Billeder på vaeggene af børnebørn eller rejser, et billedalbum eller andet, alt siger jo noget om hvem det er, jeg sidder hos (...) Der har vaeret et liv for den her dag (...)". Hun (vågeren red.) sætter sig godt tilrette i lænestolen ved siden af sengen (...). Hun sidder, så hun kan se kvindens ansigt" (Feltnote 01).

Når den døende gav udtryk for uro, angst, smerter eller utryghed, reagerede vågerne på dette og brugte konkret hænderne til at formidle tryghed. En hånd blev lagt på den døendes arm eller pande. Andre gange var vågeren tilbageholdende med at bruge egne hænder, hvis vågerens fornemmelse sagde ham eller hende, at den døende ikke ville røres ved. På spørgsmålet om, hvad det kræver at være våger, svarede en våger:

"Forstå at voere indlevende og toet på og kunne vurdere, vil du vaere for dig selv (...) vil du holdes $i$ hånden, vil du snakke og samtidigt lade vedkommende dø (...)” (I 011).

For vågerne var døden en naturlig del af det at være menneske og et vilkår, de gav udtryk for at være fortrolige med. De brugte bevidstheden om dette fælles menneskelige vilkår fra naturens hånd som begrundelse for deres omsorgshandlinger hos den døende og knyttede det frivillige arbejde til medmenneskeligt ansvar. En våger sagde: "Når man bliver født, er det to hoender der tager imod dig. Det skal der også vaere, når du skal herfra (...)" (I 004). En yngre våger udtrykte den medmenneskelige forpligtethed således:

"Jeg toenker først og fremmest, at jeg er boerer af medmenneskelighed og at tage ansvar for hinanden (...) vi har alle et ansvar for hinanden, fordi vi er mennesker i verden" (I 001). 
Omsorgen for den døende var for mange af vågerne dermed forankret $\mathrm{i}$ selve det at være et menneske i relation med andre mennesker med fællesmenneskelige vilkår. Fødsel, liv og død udgjorde en slags klangbund af fælles menneskelig erfaring, der kunne legitimere den fremmede vågers tilstedeværelse hos den døende.

Vågernes sansende orientering $\mathrm{i}$ omsorgen blev et centralt kendetegn for den frivillige omsorgshandling, hvor brugen af sanserne også var knyttet til de muligheder det at have tid hos den døende, gav vågerne. Tiden til at være nærværende tilstede banede vej for ro i rummet hos den døende og fred til at lade borgerens død foregå til sin egen tid og i den døendes eget tempo.

\section{Tid til scerlige øjeblikke}

For vågerne var øjeblikke omkring selve døden noget, de erfarede som særlig betydningsfulde øjeblikke. Hos mange af vågerne efterlod tiden omkring en borgers død et indtryk og en erfaring, de tog med sig videre i det frivillige omsorgsarbejde som våger. En erfaren våger brugte følgende ord om dette:

"Jeg ved ikke, hvad det er. Jeg ved ikke, hvad jeg skal kalde det. En eller anden tiltroekningskraft, som gør, at når man har voeret med til afslutningen på livet, er det en soerlig situation" (I 011).

De indtryk som disse særlige situationer efterlod hos vågeren var vanskelige for vågerne at sætte ord på. Der sås en berørthed, men også en blufærdighed omkring, hvad disse særlige øjeblikke betød for vågerne. Erfaringerne blev delt i fortrolighed på fællesmøderne og var afsættet til gruppens fælles udvikling af ideer og inspiration i vågerarbejdet.

Når vågerne blev grebet af disse særlige øjeblikke, sås en særlig stemthed hos dem, en form for tilbageholdenhed i rummet, der fik vågerne til at gøre noget konkret for at vie det særlige øjeblik tid. En våger beskrev det således:

"Der var en der var utrolig bange og højlydt og ikke kunne falde til ro. Jeg toenkte: "Han er stresset. Jeg har lidt stille musik på min telefon. Så satte jeg den på. Der gik ikke et kvarter. Så faldt han til ro og åndede ud" (I 011).

Samme våger gav følgende eksempel på handlinger knyttet til selve dødens øjeblik og minutterne i forlængelse af en borgers død:

"Det var så fredeligt. Så jeg lukkede et vindue op og sad der lidt. Så ringede jeg efter en sygeplejerske. Hun kom efter en halv time" (I 011).

Vågerne handlede også her på fornemmelse for, hvad der føltes rigtigt i situationen. Der var særlige øjeblikke, hvor det at handle respektfuldt i forhold til den døende, døden og den døde borger blev langt vigtigere end at følge traditionel klokketid og normer for, hvad det var nødvendigt at bruge tid på.

\section{Stedfortrceder}

Vågerne, pårørende og de professionelle gav $\mathrm{i}$ interviewene alle udtryk for, at det, at vågerne havde tid til at sidde hos den døende, åbnede mulighed for, at de professionelle med god samvittighed kunne forlade den døende til fordel for andre opgaver, og at pårørende til den døende kunne tilbydes aflastning. Vågerne fik altid en besked af de professionelle om at "ringe, hvis der var noget", men var ellers alene med den døende

De professionelle fik gennem vågernes tilstedeværelse et mere legitimt følelsesmæssigt grundlag at forlade den døende på. En professionel italesatte det således:

"Det er så ubehageligt at gå fra en borger, hvor man toenker, at her burde jeg sidde" (I 013). 
En vågeleder udtrykte om vågernes midlertidige stedfortrædende rolle og det, vågerne gjorde, som adskilte sig fra det de professionelle gjorde og kunne:

"Det er et supplement, som kan noget helt andet end personalet kan. Nemlig at blive siddende" (I 009).

I forhold til tilbud om aflastning af den døende borgers pårørende beskrev flere af vågerne denne midlertidige stedfortrædende rolle som udvidelse af den naturlige omsorg, der kan være i familier. En våger sagde:

"Man sidder ved siden af som de pårørendes forloengede arm. Nu er det mig, der holder dig i hånden i stedet for de pårørende" (I 011).

Vågerne var bevidste om, at de pårørende var i en sårbar rolle, når de tillidsfuldt måtte bede andre om at træde til og hjælpe. Stedfortrædelsen indebar derved både et moralsk og etisk ansvar i omsorgsarbejdet, og at vågeren kunne fornemme, hvornår der skulle trædes til, og hvornår man som våger skulle træde væk, så den anden igen kunne få sin plads tilbage. En våger udtrykte det således:

"Man er også i en sårbar situation. Man siger tak til det meste, hvis man er presset og har brug for aflastning (I 001).

Vågerne fortalte om deres fornemmelser omkring at vide, om man som våger skulle være der eller i stedet trække sig tilbage. En fornemmelse de fik i den aktuelle situation og vågeopgave. En våger gav følgende eksempel:

"Jeg skulle våge. Så kom en pårørende også og sagde, at hun selv ville sidde. Så blev jeg og ventede (udenfor) for at se, om hun kunne få brug for mig igen. Nogen beslutter, de gerne selv vil vaere der, så går man jo bare hjem" (I 008).

Studiets feltobservationer viste, at vågerne indimellem var usikre på, hvornår de som den, der sad der i stedet for en anden, skulle kontakte de professionelle. Især når de professionelle ikke forud tydeliggjorde for vågeren, hvad der lå i det gentagne: "Du ringer bare, hvis der er noget", kunne vågerens midlertidige stedfortrædelse resultere i, at pårørende, der ønskede det, ikke nåede frem i tide. Den midlertidige stedfortrædelse indebar således både moralske og etiske dimensioner, hvor forvaltningen af den tillid, vågerne blev vist, ikke udelukkende lå som et ansvar hos vågerne, men i lige så høj grad hos de professionelle, der kendte den døende borger og de pårørende.

\section{Groenser i omsorgsarbejdet}

I forbindelse med deltagerobservationer i vågeforløb og vågernes fællesmøder blev det tydeligt, at både vågere og professionelle var optagede af at markere og opretholde grænserne mellem det frivillige og det professionelle arbejde. For begge parter handlede det om en markering af, at frivillige og professionelle var i besiddelse af forskellig viden, men det drejede sig også om ansvar knyttet til forskelle i autoritet, når der skulle vurderes eller træffes beslutninger i forhold til den døende. De professionelle var dem, der tog initiativ til at involvere vågerne i et plejeforløb. Dermed blev vågerne inviteret med helt ind hos den døende borger - ind i et domæne, der traditionelt er forbeholdt de professionelle med ansvar for disse palliative plejeforløb. Dette peger på, at de professionelle anerkendte den omsorg, de frivillige tilbød, og at den adskilte sig fra den omsorg, de selv kunne tilbyde. 
Ingen groenser uden undtagelser

Alle vågerne var fortrolige med deres organisationers formelle rammer for det frivillige arbejde. De oplevede disse rammer som nyttige og holdt sig inden for dem, når arbejdet foregik i kontekster, hvor de professionelle havde ansvaret. En vågeleder præciserede:

"Der er nogle veldefinerede rammer for, hvad vi må og ikke må og hvilke spilleregler, vi har. Man er neutral og bringer ikke noget politisk og religiøst ind i rummet (I 009).

Alligevel fortalte flere vågere om situationer, hvor domænegrænserne i praksis var vanskelige at opretholde. Noget vågelederen ovenfor også gav udtryk for:

"Vi deltager ikke i plejen. Vi laver ikke nogens arbejde. Når det så er sagt, er der altid undtagelser. Det er noget, der hele tiden skal kridtes op. Man kalder jo ikke på en sygeplejerske for, at hun kan roekke et glas med et sugerør. Så vil man gøre det et barnebarn eller et oldebarn ville gøre, nemlig hioelp til selvhioelp (I 009).

En borgers appel om hjælp kunne dermed kalde på omsorgshandlinger fra vågerens side, selvom handlingen principielt ikke hørte inden for de frivilliges domæne. I situationer, hvor de professionelle ikke var lige ved hånden, handlede vågerne ud fra, hvad der gav mening i den aktuelle her-og-nu situation. Dette skete på trods af en bevidsthed om, at handlingen traditionelt burde varetages af en professionel i den aktuelle kontekst. Andre situationer kaldte på at italesætte de formelle domænegrænser og markere disse på ny. En våger sagde:

"Vi har vaeret ude for at en medarbejder spørger: "kan du ikke lige holde her, mens jeg skal vende (red. Borgeren)? Og det gør vi ikke" (I 010).
I uforudsete situationer handlede vågerne på, hvad, de oplevede, gav mening her og nu i samspillet med borgeren, også selvom handlingen overskred den markerede domænegrænse mellem det frivillige og det professionelle arbejde. I den følgende feltnote ses, at den vågne og permanent sengeliggende døende borger flere gange spurgte vågeren om at hente mad og drikke, der ellers var en opgave der, når borgerens hustru ikke var hjemme, blev varetaget af de professionelle:

"Du skal ikke saette dig der, for jeg vil have mere $\emptyset l$ ". Vågeren rejser sig og siger lidt muntert: "Ups undskyld, nu skal jeg straks finde noget mere. Jeg var ikke klar over, at du drak så hurtigt". Han finder en øl mere i køleskabet" (Feltnote 06).

Deltagerobservationerne viste, at når det gjaldt opgaver relateret til mad og drikke, så opstod der situationer, hvor vågerne følte, at de af etiske og moralske grunde måtte reagere på borgerens appel. Vågerne fortalte til fællesmøderne om deres tanker og bekymringer relateret til disse dilemmafyldte situationer. Kunne borgeren måske fejlsynke maden? Hvad hvis han kastede op? Hvad hvis de professionelle ikke kom, når der blev kaldt? De fleste vågere oplevede på trods af dette, at borgerens appel om hjælp og vågerens mulighed for at hjælpe overskyggede de traditionelle markerede grænser mellem det, der var de frivilliges opgave, og det, der hørte til under de professionelles domæne. På spørgsmålet om, hvordan vågeren fandt frem til den rette handling i situationen, sagde en våger fra ovenstående feltnote:

"Jeg reagerer på de ting, jeg ser og hører. Jeg forsøger at gøre det almindelige, snakke almindeligt, gøre almindelige ting, reagere almindeligt" (Feltnote 06). 


\section{De uundgåelige dilemmaer}

For de sundhedsprofessionelle var de frivilliges dilemmaer ikke overraskende. En sygeplejerske havde oplevet en våger, der måtte hjælpe en borger, der fik noget slim galt i halsen, hvor de professionelle ikke var i nærheden. Hun sagde om dette:

"Det toenker jeg er ren borgerpligt lige at klappe ham på ryggen. Det er et dilemma, man må tage med sig, når man melder sig" (I 003).

For de professionelle kunne det være mere vanskeligt og udfordrende, hvis vågerne blandede sig i arbejde, som de professionelle mente, at de frivillige ikke havde formel faglig viden om eller autoritet til at udtale sig om. En professionel knyttet til et plejehjem sagde:

"Vi har haft nogle situationer, hvor de har haft travlt med at kigge på, hvad der var af medicin. De skal holde sig fuldstoendig voek. De skal slet ikke have en holdning til det. De må gerne sige: "Hun klager sig, eller hun kniber øjnene sammen. Vil du komme og kigge på det? Så er det vores faglige opgave at vurdere. De skal kun holde i hånd. De skal ikke andet!" (I 016).

De frivillige var på den ene side netop frivillige uden fagligt ansvar og på den anden side i besiddelse af en særlig erfaringsbaseret viden opfanget gennem det sanseorienterede omsorgsarbejde og vågerfællesskabet. Vågernes erfaringsbaserede viden gav, som det ses af ovenstående, ind imellem anledning til at markere domænegrænser tydeligt i parternes samhandlinger.

De professionelle var oftest dem, der tog initiativ til at kontakte vågerne. Hvis den døende var vågen og klar, og der var pårørende, var kontakten altid etableret efter aftale med disse. De professionelle anerkendte, at en fremmed våger hos den døende kunne bidrage til en bedre omsorg for den døen- de, end hvis den døende skulle ligge alene, men denne form for 'welcoming-work' betød på den anden side også, at de professionelle følte, de måtte vurdere, om vågerne egnede sig til deres invitation. Havde vågeren nu også viden og færdigheder, der kunne hjælpe den aktuelle situation hos den døende? Var vedkommende pålidelig? Ville invitationen af vågeren betyde, at den frivillige ville blande sig i det professionelle arbejde? Når de professionelle vurderede vågeren og vedkommendes måde at være til stede på i rummet hos den døende borger, var vågernes evne til at formidle tryghed og ro hos borgeren helt afgørende. En professionel sagde om dette:

"Den gode (våger red.) er den, hvor der er kemi, kontakt, noerhed og bølgeloengde med det samme. Behov for at holde i hånd, for at traekke sig. Det kan vaere der, hvor lindringen er. I den gode stemning sammen - hvor der er tryghed og ro. Det skal vaere en ping-pong, hvor vågeren fanger borgerens signaler" (I 016).

De professionelle havde bestemte tanker om, hvilke vågere, der ikke egnede sig til omsorgsopgaven. Den professionelle ovenfor fortsatte:

"Hvis vedkommende snakker meget eller siger noget, der er afsindigt dumt, hvis man ikke kommer ind på den der frekvens, det er skide svoert, jeg indrømmer det gerne" (I 016).

For de professionelle var denne form for 'welcoming-work', hvor vågeren var inviteret helt ind tæt på den døende borger, dermed ikke noget, der kunne varetages af hvem som helst. Man skulle som våger på den ene side have tilstrækkelig viden og fornemmelse for den særlige omsorgssituation og på den anden side være bevidst om ikke at overskride grænser knyttet til forskelle i viden og autoritet mellem de frivilliges og de professionelles omsorgsopgaver i det palliative plejeforløb. 


\section{Groenser der udvides}

De professionelle var opmærksomme på, at støtten til pårørende lå inden for den palliative pleje, omsorg og behandling til syge og døende. Alligevel oplevede de professionelle, at der ikke var tid til dette. En professionel sagde:

"Hvad er det palliation handler om? Det er selvfølgelig at lindre eventuelle symptomer og styrke livskvaliteten hos den enkelte beboer, men også altid at støtte og favne de pårørende.

Det har vi ikke tid til" (I 002).

De professionelle vurderede, at vågerne gjorde en afgørende forskel, når de aflastede pårørende både i de sidste dage og timer hen imod en borgers død, men også tidligere i det palliative plejeforløb. Flere af de professionelle var dog ambivalente og usikre på vågernes viden og færdigheder, når de påtog sig omsorgsopgaver relateret til aflastning af og støtte til pårørende. De gav udtryk for, at det måtte være vanskeligt for vågerne at afgøre, hvilke pårørende der havde brug for aflastning. En professionel sagde:

"Men de var der i hjemmet, fordi hustruen havde brug for at komme ud af det hjem (...) Hun havde brug for aflastning og han (red. den syge borger) kunne spise selv og kunne gøre mange ting selv. Det er en ny tankegang" (I 003).

Vågerne selv oplevede, at en tiltagende efterspørgsel på omsorgsopgaver relateret til aflastning af den syges pårørende handlede om et behov hos de pårørende, som de professionelle ikke kunne imødekomme. Vågerne reagerede her på et presset menneskes appel om hjælp og handlede på det. En vågeleder sagde:

"De pårørende har brug for aflastning. Det toenker jeg kunne voere et nyt landskab, som vågetjenesten skulle bevoege sig ind i" (I 009).
De nyere opgaver med aflastning af pårørende så vågerne som en væsentlig omsorgsopgave, de som frivillige kunne bidrage til at løfte. En øget efterspørgsel på disse omsorgsopgaver banede vej for en udvidelse af vågernes mere traditionelle domæne som dem, der sidder hos døende, der ikke har nogen pårørende, og gav anledning til en rekonstruering og udvidelse af grænserne for de frivillige vågeres omsorgsarbejde i det palliative plejeforløb.

\section{Diskussion}

Dette delstudies fund peger på, at tid er en væsentlig ressource, vågerne bringer ind $\mathrm{i}$ det palliative plejeforløb hos døende, som de professionelle ikke har i samme grad grundet en travl hverdag. Martinsen taler med inspiration fra Rosa (2014) om det senmodernes udfordringer med den 'accelererede tid' og den styrende klokketid, der fortrænger den tid, kroppen af natur er indrettet efter (Martinsen, 2018). De sundhedsprofessionelle er underlagt et samfundsskabt regelsæt, hvor klokketid og arbejdsopgaver med umiddelbar nytteværdi tilsyneladende har forrang for den syges tid. Hastigheden medfører en døvhed for sansningen af det levende og det, som det levende stemmer os med. Noget der har konsekvenser for udvikling af erfaringer (Martinsen, 2018). Bøgeskov (2019) udfordrer i lyset af Kierkegaard, at nutidens sundhedsprofessionelle har tendens til at henfalde til vemodige og nostalgiske følelser knyttet til de 'gamle dage', hvor man oplevede, at der var mere tid til den syge, hvilket er noget, der hos Bøgeskov ses som et udtryk for et farligt tab af øjeblikkets tid. Bøgeskov argumenterer for, at følelser relateret til oplevelser af mangel på tid måske ikke kun er et resultat af for meget arbejde, men også kan knyttes til et kvalitativt tab af mening med øjeblikkets tid, her og nu, i dag. Han påpeger om forholdet til nutiden, at det "kroever, at man modstår den konstante tilbøjelighed til at leve 
fanget enten i fortiden eller i fremtiden" (ibid., s. 64). Vågernes omsorgsarbejde i dette studie udfordrer på den baggrund også til en genopdagelse af meningsfuld og etisk omsorg knyttet til tid i her-og-nu situationer i mødet med medmennesker i plejesituationer og til alle tider. I palliative pleje- og omsorgsforløb hos døende, hvor den døendes her-og nu tid må være omsorgsarbejdets kerne, kan frivillige vågere tilføre en sansende nærværende omsorg båret af tid til at blive hos den døende. Denne form for 'welcoming-work' kræver viden hos professionelle om, hvem de frivillige er, hvad de kan og en fælles løbende dialog om de uundgåelige dilemmaer i det fælles omsorgsarbejde, hvor de professionelle er dem, der har det formelle ansvar. Således kan frivillige vågere, jf. Habermann's (1995) forskning, være et 'tredje netværk', der evner at bygge bro mellem det formelle (de professionelle) og en borgers mere uformelle netværk (naboer, familie, venner) og bidrage til at styrke sammenhængskraft i omsorgen for døende i et moderne velfærdssamfund (ibid.).

Vågerne i dette studie var organiseret gennem Ældre Sagen og Dansk Røde Kors og formelt underlagt disse organisationers politikker (se f.eks. Ældre Sagen, 2011). La Cour (2014) argumenterer for, at den organiserede frivilliges omsorg består af både en formel og en uformel side i sig har en iboende konstitutiv modsætning, der udfolder sig situationsspecifikt i mødet med den anden, og i dette studie, den døende og de pårørende. Formelt véd vågerne, at de ikke må tage del i plejeopgaver, der skal varetages af de professionelle. De er fuldt fortrolige med politikken om at "sidde på hoender" og "kun holde $i$ hånd" og ikke "tage nogens arbejde". Dette studie viser, at omsorgen i mødet med den anden dog indebærer en mere uforudsigelig og uformel side. Her finder vågeren, på trods af organisationens politikker, gennem interaktionen frem til, hvilke omsorgshandlinger, der giver bedst mening i den givne situation. Grænserne mellem de professionelles og vågernes 'domæner' overskrides eller udvides dermed, men på det sansende nærværs betingelser. Vågernes frivillige omsorgsarbejde er dermed en vekslen mellem omsorgshandlinger baseret på nærvær og her-og nu situationen, og mere traditionelle omsorgshandlinger baseret på de formelle organisationers politikker (La Cour, 2014). Det er et frivillighedens iboende paradoks, der snarere skaber dynamik, kreativitet og mening i de uforudsigelige omsorgssituationer end problemer med uklare domænegrænser mellem det frivillige og det professionelle arbejde. Dette er naturligvis kun tilfældet, såfremt omsorgsarbejdet forvaltes etisk og moralsk og dermed gavner dem, det handler om, nemlig den døende og den døendes pårørende.

\section{Studiets begrænsninger}

De involverede døende borgeres manglende stemmer er studiets største svaghed, såvel som at etiske forbehold relateret til observationer hos døende har haft konsekvenser for det begrænsede antal inkluderede vågeforløb. Flere interviews med pårørende og efterlevende ville kunne tydeliggøre vågernes omsorgshandlinger relateret til mulige forskelle i eget private hjem og i plejebolig. Studiet har ikke taget højde for de sundhedsprofessionelle deltageres forskellige faglige baggrunde. Dette kan have betydning for 'boundary-work'-analysen, fordi grænser også opsættes og forhandles i lyset af graden af faglige kompetencer og formel autoritet. Ligeledes er kønsperspektivernes mulige betydning for resultaterne heller ikke forfulgt. Der indgik både kvinder og mænd i observationer og interviews, og begge køn er repræsenteret i de udvalgte citater. Begge vågegrupper havde en overvægt af kvinder, hvilket understøtter andre studiers fokus på omsorgsarbejde som feminiseret og lavstatus arbejde. Studiets del- 
tagerobservationer tog afsæt i vågerperspektivet. Pårørende og professionelle indgik kun i interviews, hvor de havde tilknytning til palliative plejeforløb med vågere involveret. Samarbejdet mellem de involverede parter på tværs er derfor mindre belyst, selvom fund relateret til grænser i samarbejdet belyses.

\section{Konklusion}

Vågeres frivillige og ulønnede arbejde hos døende borgere i eget hjem er kendetegnet ved omsorgshandlinger motiveret af et fælles medmenneskeligt ansvar for døende og deres pårørende. Vågernes brug af egne sanser i mødet med den døende er afgørende for at tyde og forstå den døendes behov. Erfaringer med særlige øjeblikke i mødet med den døende og døden har betydning for valg af handlinger i det uforudsigelige vågerarbejde. Vågerne har rolle som midlertidig stedfortræder for professionelle, der i en travl hverdag

\section{REFERENCER}

Abrahamsen, J. F. (2010). Undersøkelse om frivillige tjenester på norske sykehjem. Omsorg: Nordisk tidsskrift for palliativ medicin, 1, 31-34. Alvsvåg, H. (2015). Omsorgsfilosofi: Kari Martinsen. I Ann Marriner Tomey \& Martha Raile Alligood (red.). Sygeplejeteoretikere - bidrag og betydning for moderne sygepleje (s. 181-205), 1. udg.. København: Munksgaard.

Bertelsen, J. (2015). Kan frivillighed redde velfærden? Debatindlæg, tilgængelig på: https:// www.berlingske.dk/kommentatorer/kan-frivillighed-redde-velfaerden.

Boje, T. P. (2017). Civilsamfund, medborgerskab og deltagelse. København: Hans Reitzels Forlag.

Braun, V. \& Clarke, V. (2006). Using thematic analysis in psychology. I Qualitative Research in Psychology, 3(2),77-101.

Brinkmann, S. (2015). Etik i en kvalitativ verden. I Svend Brinkmann \& Lene Tanggaard (red.), ikke har tid til at sidde hos døende. Vågerne aflaster pårørende til den døende, når de midlertidigt træder i den pårørendes sted, og sidder hos den døende en tid i stedet for den pårørende. Vågernes stedfortrædende omsorgshandlinger indebærer et moralsk og etisk ansvar knyttet til det frivillige omsorgsarbejde i forvaltning af den magt vågerne tillidsfuldt gives, når de sidder alene og usynlig for andre hos den døende.

Domænegrænser mellem det frivillige og det professionelle arbejde genforhandles og/ eller opretholdes af både vågerne og de professionelle. I omsorgsarbejdet hos døende, hvor frivillige er inviteret ind i plejeforløbet hos den døende af de professionelle i de professionelles domæne, udfoldes frivillighedens iboende paradoks. Her ikke bare opretholdes, men også overskrides og udvides domænegrænser med udgangspunkt i en situationsspecifik omsorg på nærværets betingelser for døende og den døendes pårørende.
Kvalitative metoder, en grundbog (s. 463-479), 2. udg.. København: Hans Reitzels Forlag.

Bøgeskov, B. O. (2019). Meningsløs og meningsfuld tid i sygepleje. I Nana Vaaben \& Mie Plotnikof (red.), Tid til Velfoerd? Tidsorganisering $i$ velfoerdsprofessionerne (s. 59-79). København: Hans Reitzels Forlag.

Candy, B., France, R., Low, J. \& Sampson, L. (2015). Does involving volunteers in the provision of palliative care make a difference to patient and family wellbeing? A systematic review of quantitative and qualitative evidence. International Journal of Nursing Studies, 52, 766-768.

Claxton-Oldfield, S. \& Claxton Oldfield, J. (2007). The impact of volunteering in hospice and palliative care, i American Journal of Hospice and Palliative Medicine, 24(4),259-263.

Dansk Røde Kors (2018). Statusrapport 2017. Vågetjenesten Røde Kors. Ikke tilgængelig på net- 
tet. Kan fås ved henvendelse til vågetjenesten Dansk Røde Kors (se note 2).

Dansk Røde Kors (2019). Vågetjenesten, Status 2018. Ikke tilgængelig på nettet. Kan fås ved henvendelse til vågetjenesten Dansk Røde Kors.

DSR (2011). Dilemma: De frivilliges arbejdsindsats

- Skal man vore sygeplejerske for at kunne servere saftevand? Hvor går groensen for hvad de frivillige må tage sig af? Debatindlæg af Erik Weye, tilgængelig på: https://dsr.dk/sygeplejersken/ arkiv/sy-nr-2011-4/dilemma-de-frivilliges-arbejdsindsats.

FOA (2017). Frivilligt ulønnet arbejde gør en forskal. FOA's A-kasse, tilgængelig på: file:///C:/ Users/kss3/Downloads/Frivilligt-uloennet-arbejde-goer-en-forskel_Juli_2017\%20(1).pdf.

Fournier, V. (2000). Boundary work and the (un) making of the professions. I Nigel Malin (red.), Professionalism, Boundaries and the Workplace. London: Routledge.

Fristrup, T. \& Holm Laursen, K. G. (2017). Vågekonens sanselige orientering - om skrøbelighed og altruistisk individualisme i den palliative omsorg. Omsorg: Nordisk tidsskrift for palliativ medisin, 4, 19-23.

GDPR (2018). Datatilsynet. https://www.datatilsynet.dk/generelt-om-databeskyttelse/lovgivning/

Gyerin, T. F. (1983). Boundary-work and the demarcation of science from non-science: Strains and interests in professional ideologies of scientists. American Sociological Review, 48(6), 781-795.

Habermann, U. (1995). Det tredje netvoerk: Grundbog om frivilligt socialt arbejde. København: Akademisk Forlag.

Henriksen, L. S., Strømsnes, K. \& Svedberg, L. (2019). Understanding Civic Engagement in the Scandinavian Context. I Lars Skov Henriksen, Kristin Srømsnes \& Lars Svedberg (red.), Civic Engagement in Scandinavia: Volunteering, Informal Help and Giving in Denmark, Norway and Sweden. Berlin: Springer.

Hillestad, E. \& Tessem, J. (2015). Frivillighet i eldreomsorgen - hvorfor og hvordan?. I Marianne Sætrang Holm \& Steinar Husebø (red.), En verdig alderdom: Omsorg ved livets slutt (s. 173-184). Bergen: Fakbokforlaget/Verdighetscenteret.
Howlett, S. \& Scott, R. (2018). Pulling it all together, i Ros Scott \& Steven Howlett (red.). The Changing Face of Volunteering in Hospice and Palliative Care: An international perspective (s. 208-218). Oxford: University Press..

Jacobsen, M. H. (2011). Dødens dekonstruktion om død og udødelighed i kulturanalytisk og samtidshistorisk belysning, i Regner Birkelund (red.): Ved livets afslutning - om palliativ omsorg, pleje og behandling (s. 13-41). Aarhus: Aarhus Universitetsforlag.

Jarlbæk, L. (2017). Dødssted i Danmark 20122014. Relateret til dødsårsager, alder, køn, regioner og kommuner. Videncenter for Rehabilitering og Palliation. Notat. 4. juni 2017. Tilgængelig på: http://www.rehpa.dk/wp-content/uploads/2017/06/2017-4_D\%C3\%B8dssted-DK-2012-2014-final.pdf.

Kristiansen, S. \& Krogstrup, H. K. (2015). Deltagende observation, 2. udg. København: Hans Reitzels Forlag,.

La Cour, A. (2014). Frivillighedens logik og dens politik. København: Nyt fra Samfundslitteratur.

Lamont, M. \& Molnár, V. (2002). The study of boundaries in the social sciences. Annual Review of Sociology, 28,167-195.

Martinsen, K. (2000). Fra Marx til Løgstrup. København: Bogklubben for Sygeplejersker.

Martinsen, K. (2018). Bevegelig berørt. Med bidrag fra Tom A. Kjær. Bergen: Fakbokforlaget.

Morris S., Wilmot, A., Hill, A., Ockenden, N. \& Payne, S. (2013). A narrative literature review of the contribution of volunteers in end-oflife care services. Palliative Medicine, 27(5), 428-436.

Overgaard, C. (2014a). The boundaries of care work: A comparative study of professionals and volunteers in Denmark and Australia. Health and Social Care, 23(4), 380-388.

Overgaard, C. (2014b). De frivilliges styrke i omsorgsarbejdet. Sygeplejersken, 7, 72-76.

Poort, J. (2010). Frivilligt arbejde i sygehusregi. Omsorg: Nordisk tidsskrift for palliativ Medisin, 1, 25-30.

Riisgaard, H. (2015). Vågekoner - frivilligkorps ved dødsforløb. Omsorg: Nordisk tidsskrift for palliativ medisin, 2, 41-48.

Rosa, H. (2014). Fremmedgørelse og acceleration. København: Hans Reitzels Forlag. 
Schwartz-Nielsen, K. H. \& Raunkiær, M. (2015). Status over den palliative indsats på danske plejefaciliteter. Sygeplejersken, 6, 96-99.

Spile, M. (2018). Sygepleje til den døende patient. Susanne Jastrup \& Dorte Helving Rasmussen (red.), Klinik: Grundbog i sygepleje, 2. udg. København: Munksgaard.

Sundheds- og Ældreministeriet (2016). National undersøgelse af forholdene på plejecentre. Tilgængelig på: https://sum.dk/ /media/ Filer\%20-\%20Publikationer_i_pdf/2016/National-undersoegelse-af-forholdene-paa-plejec/ Undersoegelse-af-forholdene-paa-plejecentre. pdf.

Sundhedsstyrelsen (2017): Anbefalinger for den palliative indsats, tilgængelig på: https:// www.sst.dk/da/sygdom-og-behandling/ / media/79CB83AB4DF74C80837BAAAD55347D0D.ashx.

Tanggaard, L. \& Brinkmann, S. (2015). Interviewet: Samtalen som forskningsmetode. I Svend Brinkmann \& Lene Tanggaard (red.), Kvalitative metoder: En grundbog (s. 29-53), 2. udgave. København: Hans Reitzels Forlag,.

Timm, H. (2014). Historien om palliation i Danmark. Omsorg: Nordisk tidsskrift for palliativ medisin, 3, 15-19.

Uddannelses og forskningsministeriet (2014). The Danish Code of Conduct for Research Integrity.
Tilgængelig på: https://ufm.dk/en/publications/2014/the-danish-code-of-conduct-for-research-integrity.

Van Bochove, M., Tonkens, E., Verplanke, L. \& Roggeveen, S. (2018). Reconstructing the professional domain: Boundary work of professionals and volunteers in the context of social service reform, i Current Sociology, 66(3), 392-411.

Walshe C., Dodd, S., Hill, M., Ockenden, N., Payne, S., Preston, N. \& Algorta, G. P. (2016). How effective are volunteers at supporting people in their last year of life? A pragmatic randomised wait-list trial in palliative care (ELSA). BMC Medicine, 14, 203.

Wilson D. M., Justice, C., Roger, T. \& Sheps, S. (2005). End-of-life care volunteers: a systematic review of the literature. Health Services Management Research, 18(4), 244-257.

Ældre Sagen (2011). Frivillighedspolitik. København: Ældre Sagens Tryk.

Ældre Sagen (2019a). Ingen skal være alene i livets sidste timer. Tilgængelig på: https://www. aeldresagen.dk/historier/ingen-skal-vaere-alene-i-livets-sidste-timer.

Ældre Sagen (2019b). Vågetjenesten. Status 2018. Tilgængelig på: file://C:/Users/kss3/Downloads/Vaagetjeneste_Statusrapport_2018.pdf.

Karen Sangild Stølen, lekor, ph.d.

Institut for Sygeplejerske- og Ernæringsuddannelser, Københavns Professionshøjskole e-mail: Kss3@kp.dk

Michael Hviid Jacobsen, professor, ph.d.

Institut for Sociologi og Socialt Arbejde, Aalborg Universitet

e-mail:mhj@socsci.aau.dk

Mette Raunkiær, seniorforsker, ph.d.

Videncenter for Rehabilitering og Palliation, Syddansk Universitet

e-mail: Mette.raunkiaer@rsyd.dk 